ISSN: 2146-3042

DOI: $10.25095 /$ mufad.756250

\title{
Katılım Bankalarının CAMELS Analizi Yöntemiyle Finansal Performanslarının Değerlendirilmesi*
}

\author{
Fatma AKYÜZ** \\ Arif Şevket SOBA*** \\ Tolga YEŞİL****
}

\begin{tabular}{|c|}
\hline$\ddot{O} Z E T$ \\
\hline $\begin{array}{l}\text { Bankacılık sistemi kişilerin ihtiyaçlarına göre faizsiz bankacılık sistemi kapsamında katılım bankacılı̆̆ı alternatif bir } \\
\text { yapıya sahiptir. Klasik bankacılık sisteminde faizle işlem yapılırken, Katılım bankacılık sisteminde kâr payı esas alınmıştır. } \\
\text { Faizle işlem yapmak istemeyen kişiler ve işletmeler, ihtiyaçları ve düşünceleri gereği katılım bankacılık sistemine } \\
\text { yönelmektedir. Böylece, İslami kurallara göre ortaya çıkan katılım bankacılık sistemi diğer bankacılık türlerine göre farklı } \\
\text { bir yapıdadır. Katılım bankacılık sistemi, faizli sisteme karşı olarak ortaya çıkmış olup, atıl kalan fonların ekonomiye dâhil } \\
\text { edilmesini sağlamak amacıyla kâr-zarar paylaşımına göre faaliyet gösteren bir sistemdir. }\end{array}$ \\
\hline $\begin{array}{l}\text { Bu araştırmanın amacı, Türkiye'de faaliyet gösteren katılım bankalarının 2013-2017 yılları arasındaki CAMELS } \\
\text { Analizi ile verilerin karşılaştırılması yapılarak bankaların performanslarının ölçülmesidir. Analiz sonucunda, genel olarak } \\
\text { katılım bankalarının CAMELS puanlarında } 2015 \text { yılından itibaren düşüş yaşandığı tespit edilmiştir. }\end{array}$ \\
\hline $\begin{array}{l}\text { Anahtar Kelimeler: Katılım Bankası, Finansal Performans, CAMELS Analizi. } \\
\text { JEL Sınıflandırması: G21, G17, G10. }\end{array}$ \\
\hline
\end{tabular}

\begin{abstract}
Evaluation Of Financial Performance Of Participation Banks With CAMELS Analysis Method

ABSTRACT

The banking system differs according to the needs of individuals as classic banking and participation banking. In the classical banking system, interest transactions are carried out, while the profit sharing system is based on the Participation Banking System. Persons and businesses that do not want to trade with interest are turning to participation banking system due to their needs and thoughts. Thus, the participation banking system that emerged according to Islamic rules became an alternative to the classical banking system. Participation banking system has emerged as opposed to the interest rate system and is a system that operates according to profit and loss sharing in order to ensure the inclusion of idle funds in the economy.

The purpose of this research, participation banks operating in Turkey, making the comparison of data analysis by CAMELS between the years 2013-2017 is to measure the performance of banks. As a result of the analysis, it has been observed that CAMELS scores of participation banks have decreased in general since 2015.

Keywords: Participation Banking, Financial Performance, CAMELS Analyses.

Jel Classification: G21, G17, G10.
\end{abstract}

\footnotetext{
* Bu çalışma, Dr. Öğr. Üyesi Fatma AKYÜZ danışmanlığında yürütülmüş olan Arif Şevket SOBA' nın yüksek lisans tezinden üretilmiştir.

Makale Gönderim Tarihi: 19.08.2019, Makale Kabul Tarihi: 22.10.2019, Makale Türü: Nicel Araştırma ** Dr. Öğr. Üyesi, Uşak Üniversitesi, İktisadi ve İdari Bilimler Fakültesi, fatma.akyuz@usak.edu.tr, ORCID ID: 0000-0002-7309-1586.

*** Uşak Üniversitesi, Sosyal Bilimler Enstitüsü, arifsevket53@hotmail.com, ORCID ID: 0000-0001-6091-1672.

**** Dr. Öğr. Gör., Uşak Üniversitesi, Banaz Meslek Yüksekokulu, tolga.yesil@usak.edu.tr, ORCID ID: 00000002-3751-5222.
} 


\section{GİRIŞ}

Banka teriminin kökenine bakıldığında İtalyanca banco kelimesinden gelmekte olup, en bilinen şekliyle sıra, tezgâh, masa anlamlarına gelmektedir (Parasız, 2000, s. 5). Bankacıllk terimi; kişilerin ve işletmelerin tasarruf ve mevduatlarını biriktirerek buradan sağlanan gelirleri kredi olarak aktaran, senet ve alacak tahsilatı yapan, çeşitli hesap işlerinin ödemelerinde aracılık sağlayan finansal kurumlar olarak tanımlanabilir (Altan, 2001, s. 41).

Bankalar kişilere ve işletmelere düzenli olarak kredi hizmeti verip, krediye ihtiyacı olanların kısa veya uzun vadede onların ihtiyaçlarını karşlayarak faaliyetlerini verimli bir şekilde yürütmesine olanak sağlamaktadır. Bu bakımdan banka sağladığı kredi hizmetinden dolayı faiz getirisi elde ederken, kişiler ve işletmeler de ekonomik anlamda fayda elde etmiş olacaklardır. Bunun dışında bankalar, kişilerin mevduat hesabı açip mevduatlarını kullanmasını sağlayan, değerli eşyalarını ve nakitlerini muhafaza eden, ekonomik faaliyet gösteren kurumlardır.

Türkiye'de faaliyet gösteren bankalar; Kamusal Sermayeli Mevduat Bankaları 3 adet, Özel Sermeyeli Mevduat Bankaları 9 adet, Tasarruf Mevduatı Sigorta Fonuna Devredilen Mevduat Bankaları 1 adet, Yabanc1 Sermayeli Mevduat Bankaları 21 adet, Kamusal Sermayeli Kalkınma-Yatırım Bankaları 3 adet, Özel Sermayeli Kalkınma-Yatırım Bankaları 6 adet, Yabanc1 Sermayeli Kalkınma-Yatırım Bankaları 4 adet, Kamusal Sermayeli Katılım Bankaları 2 adet ve Yabancı Sermayeli Katılım Bankaları 3 adet bulunmaktadır (Türkiye Bankalar Birliği, [TBB], Erişim Tarihi: 16.03.2018).

Çalışmada ilk olarak katılım bankacılığı sistemi açıklanarak literatür taraması yapılmıştır. Çalışmanın diğer bölümlerde sırasıyla çalışmanın amacı, veri toplama ve CAMELS analizi, bulgular ve sonuç kısmına yer verilmiştir.

\section{LITERATÜR}

Çalışmada bankacılık sektöründe finansal performans ölçüm analiz yöntemlerinden CAMELS Analiz yöntemi kullanılmıştır. Dolayısıyla literatür taramasında CAMELS analizi ve bankacılık sektörünü inceleyen çalışmalara odaklanılmıştır. CAMELS analiziyle ilgili literatürde bulunan bazı çalışmalar, bu başlık altında irdelenmiştir.

Dash ve Das (2010) Hindistan bankacılık sektöründe, 58 bankanın 2003-2008 y1lları aralığındaki finansal performansını ölçmek amacıyla CAMELS analizini uygulamışlardır. Örneklemin yarısı kamusal banka, yarısı özel/yabancı sermayeli banka türlerinden oluşmaktadır. Çalışmanın sonucunda, özel / yabancı kuruluş türüne ait bankaların finansal performanslarının kamusal yapıya sahip bankalardan daha iyi bir performans sergilediği belirtilmiştir. Kamusal yapıya sahip bankaların pazarın değişen koşullarına hızlı bir şekilde adapte olabildiği takdirde başarılı olabileceğini çalışmada yazarlar tarafından önerilmiştir.

Williams (2011) Nijerya bankacılık sektöründeki verileri kullanarak CAMELS analiziyle birlikte eş-bütünleşim (co-integration) testini de kullanarak bir model geliştirmiştir. Analiz aşamasında, Nijerya'daki bankacılık karakteristik yapısı, finansal durum ve makro ekonomik koşulları da dikkate almıştır. Çalışmanın bulgular ve sonuç kısmında Nijerya 
bankacıllk sektöründe sermaye yeterliliği için para arzının önemli bir belirleyici faktör olduğunu belirtilmiştir.

Aytekin ve Sakarya (2013) çalışmalarında, 2001 yerel finansal krizi ve 2008 küresel finansal krizden etkilenen ve Borsa İstanbul'da işlem gören mevduat bankalarının, CAMELS yöntemi ile analizini yapmışlardır. Çalışmalarında krizin yaşandığı iki dönem baz alınarak dönem öncesi ve dönem sonrası bakımından bankaların durumları incelenmiştir. Çalışma sonucunda, CAMELS performanslarında dalgalanmaların yaşandığı görülmüştür. Kriz öncesi ve sonrasındaki dönemlerde mevduat bankalarının CAMELS puanları arasında istatistiksel olarak anlamlı bir fark bulunamadığı tespit edilmiştir.

Kandemir ve Demirel Arıcı (2013) çalışmalarına göre, Türkiye'deki mevduat bankalarının 2001-2010 yılları arasındaki mülkiyet yapılarına göre gruplandırma yaparak performanslarının grup bazında karşılaştırmalı olarak incelenmişlerdir. Bankaların performanslarını incelemede CAMELS performans değerleme modelini kullanmışlardır. Yapılan incelemeler doğrultusunda 2001 bankacılık krizi sonrasında mevduat bankalarında likidite ve yüksek sermaye yeterlilik oranlarına sahip olup, krizlere karşı tedbirli bir şekilde hareket etmişlerdir. Ayrıca incelenen dönemde, yabancı sermayeli mevduat bankalarının yönetim kalitesi ve aktif kalitesi bakımından en iyi performans göstermekte olan grup olup, piyasa risklerine karşı diğer gruplara göre daha duyarlı olduğunu tespit etmişlerdir.

Ege, Topaloğlu ve Karakozak (2015) çalışmalarında, Türk bankacılık sektöründe yer alan kamu, özel ve yabancı sermayeli mevduat bankalarının mevduat durumlarını belirlemek amacıyla CAMELS analiz yöntemi ile inceleme yapmışlardır. Çalışmada 2002-2010 yılları arasındaki veriler doğrultusunda banka grupları arasında karşılaştırma yapılarak analiz edilmiştir. Analiz sonuçlarına göre sermaye yeterliliği, yönetim yeterliliği ve piyasa riskine duyarlılık bakımından kamu sermayeli mevduat bankaları iyi seviyede görülmüştür. Kârlılık olarak özel sermayeli bankalarda olumlu durum gözlemlenmiştir. Likidite ve aktif kalitesi bakımından ise yabancı sermayeli mevduat bankalarının diğer banka gruplarına göre daha güçlü bir düzeyde olduğu analiz sonuçlarında belirlenmiştir.

Gümüş ve Nalbantoğlu (2015) çalışmalarında, Türkiye'de faaliyet gösteren kamu, yerli özel, yabancı ve katılım bankaları olarak dört farklı alandaki grupları 2002-2013 yılları arasında CAMELS performans analizi yöntemiyle karşılaştırarak inceleme yapmışlardır. Bankacılık Düzenleme ve Denetleme Kurumunun kontrolü altındaki bankaların bilançolarında iyileşme olduğu görülmektedir. Çalışmada yerli özel sermayeli bankalar kârlılık ve yönetim kalitesinde gösterdiği yüksek performans ve kuvvetli sermaye yapılarıyla en fazla nota sahip olan banka grupları olduğu tespit edilmiştir. Kamu bankaları, 2001 krizinden sonra aktiflerinde gerçekleştirdiği düzelmeleri ve kuvvetli sermaye yapılarıyla ikinci sırada yer aldığı belirlenmiş̧tir. Yabancı bankalarda takip oranlarının yükselmesiyle yönetim kalitesi ve kârllık üzerinde olumsuz bir durum gözlemlenmiştir. Katılım bankalarında faizsiz bankacılık ilkelerini kullanım şartları gereği, sermayelerinin diğer banka gruplarına göre zayıf kalması nedeniyle aktiflerindeki fon işlemlerinin fazlalığı olumsuz etki göstermiştir.

Ateşoğlu Coşkun ve Karğın (2016) çalışmalarında bankaların farklı ülkede gerçekleştirmiş olduğu sınır ötesi birleşmelerin, bankaların mali performanslarına etkilerini CAMELS analizi yöntemiyle incelenmişlerdir. Türkiye'de gerçekleşmiş olan 3 sınır ötesi 
banka birleşmeleri (Finansbank, Denizbank, ING Bank) CAMELS analizine göre finansal incelemeleri yapılmıştır. Satın alınma öncesi üç yılı ve satın alınma sonrasındaki üç yıllık dönemi için, mevduat bankalarının ortalamalarıyla karşılaştırılarak performans değerlemesi yapılmıştır. İncelemeler sonucunda satın alma sonrasındaki dönemde yabancı bankaların satın almış olduğu bankaların performanslarında düşüş yaşandığı görülmektedir.

Genel anlamda literatür taramasındaki çalışmalarda mevduat bankalarının CAMELS Analiz yöntemiyle finansal performanslarının ölçüldüğü dikkat çekmektedir. Bu çalışmada ise katılım bankalarına CAMELS Analiz yöntem uygulanması özgünlük kazandırmaktadır.

\section{KATILIM BANKACILIĞI}

Katılım Bankac1lığı, ekonomik hayatı İslami usul ve esaslara göre düzenleyen, finansal sistem içinde faaliyet gösteren, faizsiz finans olarak tanımlanan sistemi ifade etmektedir. Katılım Bankacılığı; İslam dininin kurallarından yola çıkıp, kişilerin bankacılıkla ilgili birçok işlemlerini yapması ve ellerindeki nakitleri en uygun biçimde değerlendirmesini sağlamak amacıyla kurulan, İslam dini ihtiyaçlarına uygun olarak hizmet veren bir kurum olarak görülmektedir (Karhan, 2015, s. 43). Katılım Bankacılık Sisteminin finansal işlemlerinde risk; kâr veya zarar olarak pay edilmektedir (El Qorchi, 2005, s. 1). Katılım Bankacılığı diğer bankacilık türleri gibi gelişme gösteren sistem olup, kâr paylaşımı temeline dayanmaktadır (Iqbal ve Molyneux, 2005, s. 18).

Katılım Bankacıllı̆ı Sistemi, islami kurallara göre ortaya çıkmış olsa da, ekonomik krizlerin sebebi olarak gösterilen diğer bankacılık sistemleri yerine alternatif olarak önem kazanmıştır. $\mathrm{Bu}$ bankaların uygulamaya koydukları yöntemlerinde faiz kavramının olmayışından dolayı İslami bankacılık veya faizsiz bankacılık adını almıştır. Katııı Bankacılık kavramı yerine literatürde yaygın olarak "İslami Bankacılık" kavramı daha çok kullanılmaktadır.

Katılım Bankacılı̆ğ 1950'li yıllarda ortaya çıkmakta olup tarihi daha eski zamanlara dayanmaktadır. Pakistanlı Muhammed Uzair 1955 yılında Katılım Bankacılığı alanında araştırmayı ilk yapan bilim adamıdır. Mit Ghambr bankası Mısır'da 1963 yılında faizsiz bankacıllk faaliyete geçmiş olup, Nasser Social Bank Kahire'de 1972 yılında modern anlamda kurulan ilk faizsiz bankadır. Faizsiz bankacılık ortaya çıktığı ilk andan itibaren gelişimini arttırmıştır. Bu bağlamda 1975 yılında Türkiye'nin de dâhil olduğu 43 devletin girişimiyle İslam Kalkınma Bankası faaliyete geçmiştir. (Türkmenoğlu, 2007, s. 12-13).

Türkiye'nin Katılım Bankacılığı Sistemiyle karşılaşması 1980 yıllarında uluslararası piyasalar ile uyum sağlamaya çalışmasıyla mümkün olmuştur. Türkiye'de finansal sistem 1980 yıllarında çeşitlilik ve farklılaşma konusunda gelişme göstermiştir. Hazine ve Dış Ticaret Müsteşarlığı 25 Şubat 1984 tarihinde, T.C. Merkez Bankası'nın 21 Mart 1984 tarihinde tebliğlerin yayımlanmasıyla sistemin detayları düzenlenmiş̧tir. Bu düzenlemeler ve tebliğlerin sonunda sistemin mevzuat altyapısı hazırlanmıştır (Eskici, 2007, s. 26).

Katılım bankası nitelikleri Tablo 1'de gösterilmiştir (Sunbat, 2016, s. 24-26); 
Tablo 1. Katılım Bankasının Nitelikleri

\begin{tabular}{|c|c|}
\hline Nitelikler & Açıklama \\
\hline $\begin{array}{l}\text { Banka Niteliğine } \\
\text { Sahip Olması }\end{array}$ & $\begin{array}{l}\text { Bankacıllk türlerinden biri olan Katılım bankaları } 2005 \text { yılında çıkarılan } 5411 \text { sayılı } \\
\text { Bankacılık Kanunuyla banka türlerinden biri olmuştur. Bankacılık Düzenleme ve } \\
\text { Denetleme Kurulu kararı ile Katılım bankası faaliyete geçmiştir. Katılım bankaları, } \\
\text { faizsiz bankacılık prensiplerine uygun olarak devamlı idari inceleme altında olup } \\
\text { denetimlerden geçmektedir. }\end{array}$ \\
\hline $\begin{array}{l}\text { Faizsiz Bankacilık } \\
\text { Faaliyeti Yapması }\end{array}$ & $\begin{array}{l}\text { Para, İslam dinine göre bir değişim aracı ve değer ölçüsüdür. Para kendiliğinden } \\
\text { artmaz ve kazanç getirmez. Piyasa imkanlarının ortaya çıardığı elde olmayan } \\
\text { hareketlenmeler haricinde paranın kuymetinin değişim göstermemesi ve bir ağırlık } \\
\text { birimi gibi kıymetinin muhafaza edilmesi gerekmektedir. Alım-satım yaparak ya da } \\
\text { kişilere borç verilerek elde edilen kazançlar uygun bulunmamıştır. Ticari malların } \\
\text { üzerinden alım-satımı yapılan malların kazançları ise kâr olarak ifade edilmektedir. } \\
\text { Katılım Bankacılık Sistemi faizsiz işlemler yaparak kişilere faizsiz bankacılık } \\
\text { usullerine göre finansal araçlar geliştirip, klasik bankaların tersine faiz olarak ifade } \\
\text { edilmeyip kâr payı olarak ele alınmaktadır. }\end{array}$ \\
\hline $\begin{array}{l}\text { Aracı } \\
\text { Niteliğine } \\
\text { Olması }\end{array}$ & $\begin{array}{l}\text { Dünyada kişilerin bir bölümü dini inançları gereğince faizle işlem yapmamakla } \\
\text { beraber ellerindeki fonlar ekonomiye katkı sağlamamaktadır. Bu kişilerin iş } \\
\text { yapabilmesi için ihtiyacı olan nakit parayı temin etmeleri gerekmektedir. Katılım } \\
\text { Bankacılık Sistemi finansal alanda klasik bankaları kullanmayan kişilerin fonlarının } \\
\text { ekonomiye kazandırılarak bunların güvenli bir şekilde korunması ve değerinin } \\
\text { arttırılmasına katkı sağlamak için faaliyete geçmiştir. Katılım Bankacılık Sistemi } \\
\text { yatırımcılara birçok yeni farklı seçenekler sunmaktadır. Katılım bankaları kâr ve } \\
\text { zarara ortak olma esasına göre faaliyet gösteren bir kuruluştur. Bu bankalar verimli } \\
\text { fon kullandırmasıyla ekonomik ve mali krizlerden daha düşük seviyede zarar } \\
\text { görmektedir. }\end{array}$ \\
\hline $\begin{array}{lr}\text { Güven } & \text { Kurumu } \\
\text { Niteliğine } & \text { Sahip } \\
\text { Olması } & \\
\end{array}$ & $\begin{array}{l}\text { Klasik bankalar faiz getirisi kesin olmakla beraber katılım bankaları, kâra veya zarara } \\
\text { ortak olma ilkelerine göre faaliyet gösteren bir bankacılık sistemidir. Katılım } \\
\text { Bankac1lık Sisteminde kâr getirisinin kesinliği olmayıp elde edilen paranın faydalı bir } \\
\text { şekilde kullanılacağına yönelik güven oluşturmas gibi sorumlulukları da vardır. Bu } \\
\text { durum Katılım Bankacıllı Sistemine olan güveni ifade etmektedir. }\end{array}$ \\
\hline
\end{tabular}

Kaynak: Sunbat, 2016, s. 24-26 kaynağında yer alan bilgilerden derlenerek yazarlar tarafından hazırlanmıştır.

Katılım Bankacılığı, banka hizmetlerinin dışında kişilere faizsiz seçenekler sunup ve bir araya getirdikleri fonları kâr-zarar ortaklığı ilkeleriyle, sınai ve ticari faaliyetlerin finansmanında kullanmasına olanak sağlayan sistemdir (Özulucan ve Deran, 2009, s. 88). Faizsiz bankacılık olarak bilinen bu işletmelerin çalışma ilkeleri şunlardır (Avcu, 2015, s. 15$17)$;

- $\quad$ Faizin yasak olmas1,

- Kâr-zarar risk paylaşımı,

- Faaliyet alanlarının belirli olmasi,

- $\quad$ Spekülasyonun yasak olması,

- $\quad$ Faaliyetlerinin şeffaf olması.

Katılım bankacılık sistemi, diğer bankacılık sistemlerinden fon toplanması ve değerlendirilmesi bakımından farklılık göstermekle beraber katılım bankaları; cari hesap açma, senet ve çeklerin tahsilatı, dövizlerin alım satımları, transfer ve havale işlemleri, elektrik, su, telefon, doğalgaz faturaları işlemleri, kredi kartı, bankamatik gibi hizmetler sağlamaktadır. 
İslam dini kuralları gereği ticari faaliyetlerde bulunmak ve bu faaliyetlerden sağlanan kazanç uygun görülmüştür. Katılım bankacılı̆̆ sistemi kâr payı dağılımına göre faaliyette bulunan bir sistemdir. Katılım bankacıllı̆ı sisteminde diğer bankacılık sistemleriyle rekabet edilmektedir. Katılım bankacılığı sisteminin işleyiş süreci; finansman isteği olan müşterilerin bankanın kendisine verdiği vekâleti kullanarak ihtiyacı olduğu mal ya da varlığı banka adına satın almaktadır. Geri ödeme planı, anlaşılan kâra göre belirlenip, vadeye ayrılarak gerçekleştirilmektedir. Bu ticari faaliyetten sağlanan kâr, katılma hesabı müşterisine pay edilmektedir (Türkiye Finans, Erişim Tarihi: 16.01.2018).

\section{4. ÇALIŞMANIN AMACI VE ÖNEMİ}

Bu çalışmada Türkiye'de faaliyet gösteren katılım bankalarının 2013-2017 yılları arasındaki CAMELS Analizi ile verilerin karşılaştırılması yapılarak bankaların performanslarının ölçülmesi amaçlanmıştır.

CAMELS analizinde ortaya çıkabilecek risklere karşı önceden önlem alınarak sorunlara müdahale edilebilme konusunda önem teşkil etmektedir.

\section{1. Çalışmanın Sınırlılıkları}

Çalışmanın ele alındığı yıllar itibariyle bazı bankaların söz konusu yıllar içinde faaliyette bulunmaması veya faaliyetlerini sonlandırmaları sebebiyle çalışmada bazı kısıtlar uygulanmıştır. Buna göre; Albaraka Türk Katılım Bankası, Kuveyt Türk Katılım Bankası, Türkiye Finans Katılım Bankasının 2013-2017 yılları arasındaki 5 yıllık verileri, Ziraat Katılım Bankasının 2015-2017 yılları arasındaki 3 yıllık verileri ve Vakıf Katılım Bankası 2016-2017 yılları arasındaki 2 yıllık verileri ile kısıtlanmıştır.

\subsection{Verilerin Toplanması ve Analizi}

$\mathrm{Bu}$ kapsamda bankaların performans analiz ölçümü için uygun görülmekte olan CAMELS Performans Değerleme Analizi yöntemi kullanılmıştır.

CAMELS, ABD'de (Amerika Birleşik Devletleri) denetim kuruluşlarınca oluşturulmuş olan ve mevduat bankaların risk bazlı denetim aşamasında genel durumunun belirlenmesinde ve uzaktan gözetleme faaliyetlerinde kullanılmakta olan bir değerlendirme sistemidir. CAMELS harflerini adını aldığı 6 bileşenin ilk harflerinden oluşmaktadır. Buna göre; Sermaye Yeterliliğini C (Capital); Varlık Kalitesini A (Asset Quality); Yönetim Yeterliliğini M (Management Adequacy); Kazanç Durumu E (Earnings); Likidite Durumunu L (Liquidity); Piyasa Risklerine Duyarlılığ ise S (Sensitivity to Market Risk) ifade etmektedir (Türker Kaya, 2001, s. 1). Uniform Financial Institutions Rating System (UFIRS), CAMEL modeline 1996 senesinin sonlarında revize yaparak bu model için bankanın Piyasa Risklerine Duyarlılığı (Sensitivity to Market Risk) bileşenini de ekleyerek CAMELS modeli oluşturulmuştur (Kandemir ve Demirel Arıı1, 2013, s. 65). 
CAMELS analizi derecelendirmesinde ilk önce bankaların her bir CAMELS bileşenleri için değerlendirilmesi yapılmaktadır. $\mathrm{Bu}$ amaçla birtakım finansal oranlar kullanılmakta olup, derecelendirmeler 1 ve 5 arası bir ölçek üzerinden yapılmaktadır. $\mathrm{Bu}$ duruma göre " 1 " en yüksek performansı belirten kurumu ifade ederken, derecenin artması kötüye giden durumu ifade etmektedir. Bileşenler belirlenip ayrı ayrı hesaplandıktan sonra bileşenlerin ağırlıklı ortalaması ilgili bankanın genel notunu göstermektedir. Değerlendirmeler yapılırken kullanılmakta olan ağırlıklar tam olarak denetçinin kontrolü altındadır ve bankanın büyüklüğü, yapısı, bankaya özel ve genel konularda denetçi tarafından incelenmektedir. Buna göre (Çağıl ve Mukhtarov, 2014, s. 80; Türker Kaya, 2001, s. 1-2);

“1” her bakımdan güçlü bankayı (CAMELS'i meydana getiren her bir bileşen için bankanın notu 1 veya 2 olmalıdır),

“2” genellikle güçlü bankayı (her bir bileşen değerleri 3'den kötü olmamalıdır),

"3" bankaların performanslarıyla ilgili sorunlar olduğunu, tatmin edici bir yapıda çalışmadığını, şok ihtimallerine karşı yeteri kadar güçlü olmadığını ve denetçilerin problemli bölümlere yönelmesi gerektiğini,

"4" genelde önemli sorunları olan ve yönetim/finansal olarak bozulmaların ortaya çıktığı ve bu bakımdan performansı düşük olan bankaları,

"5" çok önemli derecede yönetim/finansal sorunları olan ve batma riski yüksek olan bankaları ifade etmektedir.

CAMELS analizi sonucunda olumsuz durumda görülen bankalar, başarısız olarak nitelendirilmemektedir. Piyasanın yapıcıları CAMELS analizi sonucunu erken uyarı sistemi gibi düşünerek, ilgili bankalara odaklanmaya çalışıp finansal gücü tespit etmeye çalışmaktadırlar. Bu analizin sonucunda yalnız finansal yapısı güçsüz bankalar değil, finansal yapısı güçlü bankalar da belirlenmektedir (Abdullayev, 2013, s. 98). CAMELS Analizi göstergeleri gelişmiş ülkelerde sağlıklı çalışabilmektedir. Çünkü gelişmiş ülkelerde güçlü bir gözetim ve denetim sistemi altyapısı bulunmaktadır. Gelişmekte olan ülkelerde farklı göstergelere de ihtiyaç duyulması olasıdır (Kandemir ve Arıcı, 2013, s.66-67; Çelik, 2004, s.80-81).

CAMELS Performans Değerleme Analizinde ilk olarak katılım bankalarının TKBB'nin web sitesindeki verilerine ulaşılmıştır. $\mathrm{Bu}$ veriler doğrultusunda katılım bankalarının referans değerleri belirlenmiştir. Referans değeri belirlendikten sonra ana bileşen ve alt bileşenlere belirli yüzde oranlar verilmiştir. İlişki yönü (+/-) olarak belirlenerek her yıla ait CAMELS puanları hesaplanmıştır. belirtilen (+/-) işaretleri ilişkinin yönünü, finansal oranlar ve bu oranın karşılığı olan bileşeni arasında ilişkinin yönünü olumlu ya da olumsuz olduğunu belirlemektedir. İlgili finansal oranlar ve değerlendirme şekli Tablo 2'de sunulmuştur; 
Tablo 2. CAMELS Analizinde Kullanılan Oranlar

\begin{tabular}{|c|c|c|c|c|}
\hline CAMELS ORANLARI & $\begin{array}{l}\text { ORANLARIN } \\
\text { KISA ADLARI }\end{array}$ & $\begin{array}{l}\text { İLİ̧̧Kİ } \\
\text { YÖNÜ }\end{array}$ & $\begin{array}{l}\text { ORANA } \\
\text { VERÍLEN } \\
\text { AĞIRLIK } \\
(\%)\end{array}$ & $\begin{array}{l}\text { BİLEŞENE } \\
\text { VERILEN } \\
\text { AĞIRLIK } \\
(\%)\end{array}$ \\
\hline SERMAYE YETERLİLİ̆Ğ (C) & & & & 20 \\
\hline $\begin{array}{l}\text { Öz Kaynaklar / (Kredi }+ \text { Piyasa }+ \\
\text { Operasyonel Riske Esas Tutar) }\end{array}$ & SYO1 & + & 25 & \\
\hline Öz Kaynaklar / Toplam Aktifler & SYO2 & + & 25 & \\
\hline $\begin{array}{l}\text { (Öz Kaynaklar-Duran Aktifler) / Toplam } \\
\text { Aktifler }\end{array}$ & SYO3 & + & 25 & \\
\hline $\begin{array}{lllll}\text { Net Dönem Kârı (Zararı) / Toplam } \\
\text { Aktifler }\end{array}$ & SYO4 & + & 25 & \\
\hline AKTİF KALİTESİ (A) & & & & 20 \\
\hline $\begin{array}{l}\text { Toplam Krediler ve Alacaklar / Toplam } \\
\text { Aktifler }\end{array}$ & AKO1 & + & 25 & \\
\hline $\begin{array}{llll}\text { Takipteki Krediler (brüt) / Toplam } \\
\text { Krediler ve Alacaklar }\end{array}$ & $\mathrm{AKO} 2$ & - & 25 & \\
\hline Duran Aktifler / Toplam Aktifler & $\mathrm{AKO} 3$ & - & 25 & \\
\hline Finansal Varlıklar (net) / Toplam Aktifler & $\mathrm{AKO} 4$ & - & 25 & \\
\hline YÖNETİM KALİTESİ (M) & & & & 15 \\
\hline $\begin{array}{llll}\text { Takipteki Krediler } & \text { (brüt) / Toplam } \\
\text { Krediler ve Alacaklar } & & & \end{array}$ & YKO1 & - & 35 & \\
\hline $\begin{array}{l}\text { Şube Başına Net Kâr (Net Kâr/ Toplam } \\
\text { Şube Sayısı) (milyon TL) }\end{array}$ & YKO2 & + & 35 & \\
\hline $\begin{array}{lllll}\text { Personeli } & \text { Giderleri / Diğer Faaliyet } \\
\text { Giderleri } & & & & \\
\end{array}$ & YKO3 & - & 30 & \\
\hline KÂRLILIK (E) & & & & 15 \\
\hline $\begin{array}{l}\text { Net Dönem Kârı (Zararı) / Toplam } \\
\text { Aktifler }\end{array}$ & KO1 & + & 25 & \\
\hline Net Dönem Kârı (Zararı) / Öz kaynaklar & $\mathrm{KO} 2$ & + & 25 & \\
\hline Vergi Öncesi Kâr / Toplam Aktifler & KO3 & + & 25 & \\
\hline $\begin{array}{l}\text { Net Dönem Kârı (Zararı) / Ödenmiş } \\
\text { Sermaye }\end{array}$ & KO4 & + & 25 & \\
\hline LIKIIDITE (L) & & & & 15 \\
\hline Likit Aktifler / Toplam Aktifler & LO1 & + & 35 & \\
\hline $\begin{array}{l}\text { Likit Aktifler } \\
\text { Yükümlülükler }\end{array}$ & $\mathrm{LO} 2$ & + & 35 & \\
\hline TP Likit Aktifler / Toplam Aktifler & LO3 & + & 30 & \\
\hline PİYASA RİSKİNE DUYARLILIK (S) & & & & 15 \\
\hline YP Aktifler / YP Pasifler & PRDO1 & - & 35 & \\
\hline $\begin{array}{l}\text { Özel Karş1lıklar Sonrası Net Kâr Payı } \\
\text { Geliri / Toplam Aktifler }\end{array}$ & PRDO2 & - & 35 & \\
\hline $\begin{array}{l}\text { Döviz Pozisyonu (Yabancı Para Aktifler- } \\
\text { Yabancı Para Pasifler/ Öz kaynaklar }\end{array}$ & PRDO3 & - & 30 & \\
\hline
\end{tabular}


Bankaların CAMELS puanlarının hesaplanması aşamasında ilk olarak bankaların belirli bir dönemdeki ilgili banka değerlerinin aritmetik ortalamaları alınarak referans değerleri bulunmaktadır. Endeks değeri, banka değerinin referans değerine bölünüp 100 ile çarpılmasıyla bulunmaktadır. Sapma değerinde, ilişki yönü (+) ise endeks değerinden 100 çıkarılır, (-) ise 100'den endeks değeri çıkarılmaktadır. Ağırlıklı değerler için, finansal orana verilen ağırlıkla sapma değeri çarpılmaktadır. Finansal oranların ağırlıklı değerleri toplanarak ana bileşenin ağırlık değeri bulunmaktadır. Son olarak ana bileşenlerin ağılıklı değerinin ağırlık oranlarıyla çarpılarak diğer ana bileşenlere de aynı işlemin uygulanmasıyla sonuçların toplamı CAMELS puanını bulmaktadır. göstermektedir.

$\mathrm{Bu}$ durum Tablo 3'de CAMELS puanlarının hesaplanma aşamaları olarak

Tablo 3. CAMELS Puanlarının Hesaplanması

\begin{tabular}{|l|l|l|}
\hline İlişki Yönü & (a) & (+) ya da (-) \\
\hline Ana Bileşene Verilen Ağırlık (\%) & (b) & $\begin{array}{l}\text { Araştırmacının, toplamı \%100 olacak biçimde ana } \\
\text { bileşenlere verdiği ağırlıklı değerler }\end{array}$ \\
\hline Finansal Orana Verilen Ağırlık (\%) & (c) & $\begin{array}{l}\text { Araştırmacının, hesaplanan finansal oranlara ana bileşen } \\
\text { toplamı \%100 edecek biçimde verdiği ağırlıklı değerler }\end{array}$ \\
\hline Referans Değeri & (d) & $\begin{array}{l}\text { Belirli dönemde ilgili bankalar için hesaplanan finansal } \\
\text { oranların aritmetik ortalaması }\end{array}$ \\
\hline Banka Değeri & (e) & Belirli dönem içindeki bankanın finansal oranı \\
\hline Endeks Değeri & (f) & (e/d)*100 \\
\hline Sapma Değeri & (g) & $\begin{array}{l}\text { ̇̇lişki yönü (+) ise; (f)-100 } \\
\text { Ilişsi yönü (-) ise; 100- (f) }\end{array}$ \\
\hline Ăğırlıklı Değerler & (h) & (c*g)/100 \\
\hline CAMELS Puanı & (l) & $\sum\left(b^{*} \sum \mathrm{h}\right)$ \\
\hline
\end{tabular}

Kaynak: Arıçelik, 2010, s. 90; Aytekin ve Sakarya, 2013, s. 39; Ege vd. 2015, s. 115.

Analiz kapsamındaki katılım bankalarının hesaplanmış referans değerleri ve 20132017 yıllarına ait CAMELS puanları Tablo 4 ve Tablo 5'te sunulmuştur. 
Tablo 4. 2013-2017 Yılları Katılım Bankaları için Belirlenen Referans Değerleri

\begin{tabular}{|c|c|c|c|c|c|}
\hline ORANLAR \% & 2013 & 2014 & 2015 & 2016 & 2017 \\
\hline \multicolumn{6}{|l|}{ C } \\
\hline SYO1 & 14 & 13,97 & 22,63 & 17,82 & 13,44 \\
\hline \begin{tabular}{|l|} 
SYO2 \\
\end{tabular} & 9,2 & 8,7 & 13,6 & 10,54 & 8,68 \\
\hline SYO3 & 6,03 & 5,57 & 10,03 & 7,34 & 5,48 \\
\hline SYO4 & 1,3 & 1,07 & 0,55 & 0,68 & 1 \\
\hline \multicolumn{6}{|l|}{ A } \\
\hline AKO1 & 67,23 & 65,47 & 67,98 & 64,76 & 69,46 \\
\hline AKO2 & 2,4 & 2,33 & 2,2 & 2,68 & 2,62 \\
\hline AKO3 & 3,17 & 3,13 & 3,58 & 3,24 & 3,2 \\
\hline \begin{tabular}{|l|} 
AKO4 \\
\end{tabular} & 5,73 & 6,87 & 6,63 & 8,06 & 7,38 \\
\hline \multicolumn{6}{|l|}{$\mathbf{M}$} \\
\hline YKO1 & 2,4 & 2,33 & 2,2 & 2,68 & 2,62 \\
\hline YKO2 & 129445,13 & 121569,3 & 75719,38 & 95849,84 & 175791,94 \\
\hline YKO3 & 53,07 & 52,1 & 49,53 & 47,8 & 48,34 \\
\hline \multicolumn{6}{|l|}{$\mathbf{E}$} \\
\hline KO1 & 1,3 & 1,07 & 0,55 & 0,68 & 1 \\
\hline KO2 & 14,07 & 12,33 & 8,38 & 7,54 & 11,46 \\
\hline KO3 & 1,57 & 1,37 & 0,75 & 0,86 & 1,24 \\
\hline KO4 & 21,03 & 19,07 & 14,88 & 12,28 & 18,1 \\
\hline \multicolumn{6}{|l|}{$\mathbf{L}$} \\
\hline LO1 & 26,47 & 26,83 & 25,05 & 29,2 & 25,06 \\
\hline $\mathrm{LO2}$ & 50,83 & 47,27 & 44,08 & 52,78 & 39,5 \\
\hline LO3 & 6,87 & 6,3 & 6,35 & 9,12 & 7,12 \\
\hline \multicolumn{6}{|l|}{$\mathbf{S}$} \\
\hline PRDO1 & 56,27 & 57,7 & 63,53 & 79,12 & 69,46 \\
\hline PRDO2 & 2,5 & 2,47 & 2,43 & 1,94 & 2,12 \\
\hline PRDO3 & $-214,03$ & $-227,3$ & $-187,73$ & $-147,68$ & $-161,56$ \\
\hline
\end{tabular}


Tablo 5. Katılım Bankacılık Sisteminde 2013-2017 Y1lları Arasındaki CAMELS

Puanları

\begin{tabular}{|c|c|c|c|c|c|}
\hline & 2013 & 2014 & 2015 & 2016 & 2017 \\
\hline AlbarakaTürk & 1,06 & 1,69 & 15,49 & $-15,29$ & $-18,09$ \\
\hline $\mathbf{C}$ & 2,23 & $-2,96$ & $-13,26$ & $-27,72$ & $-15,60$ \\
\hline $\mathbf{A}$ & 5,32 & 9,40 & 3,15 & $-20,30$ & $-26,74$ \\
\hline $\mathbf{M}$ & 3,77 & 2,16 & 23,18 & $-34,82$ & $-48,29$ \\
\hline $\mathbf{E}$ & 14,46 & 16,68 & 88,37 & 29,55 & $-9,10$ \\
\hline $\mathbf{L}$ & $-20,63$ & $-13,65$ & 15,33 & $-14,76$ & 7,14 \\
\hline $\mathbf{S}$ & $-0,63$ & $-2,50$ & $-10,15$ & $-17,88$ & $-13,93$ \\
\hline KuveytTürk & $\mathbf{0 , 6 0}$ & 5,05 & 16,83 & 13,95 & 8,29 \\
\hline $\mathrm{C}$ & $-2,09$ & 7,02 & $-5,47$ & 4,94 & 13,79 \\
\hline $\bar{A}$ & 1,80 & 4,44 & 13,97 & 6,43 & 11,01 \\
\hline $\mathbf{M}$ & $-4,32$ & 0,48 & 30,17 & 14,55 & 3,22 \\
\hline $\mathbf{E}$ & $-10,49$ & $-2,57$ & 61,98 & 66,72 & 22,42 \\
\hline $\mathbf{L}$ & 20,10 & 22,13 & 12,33 & $-4,29$ & 4,46 \\
\hline $\mathbf{S}$ & $-0,91$ & $-1,65$ & $-3,60$ & 0,83 & $-7,88$ \\
\hline TürkiyeFinans & $-1,67$ & $-6,89$ & $-25,63$ & $-26,18$ & $-28,67$ \\
\hline $\mathbf{C}$ & $-0,09$ & $-4,36$ & $-31,79$ & $-21,30$ & $-5,26$ \\
\hline $\mathbf{A}$ & $-7,09$ & $-13,99$ & $-53,97$ & $-70,43$ & $-90,84$ \\
\hline $\mathbf{M}$ & 0,55 & $-2,79$ & $-31,45$ & $-33,39$ & $-47,94$ \\
\hline $\mathbf{E}$ & $-4,13$ & $-14,51$ & 1,89 & 8,55 & $-10,85$ \\
\hline $\mathbf{L}$ & 0,48 & $-8,47$ & $-20,72$ & $-22,59$ & 1,17 \\
\hline $\mathbf{S}$ & 1,55 & 4,29 & $-6,21$ & $-4,82$ & $-5,39$ \\
\hline Ziraat Katılım & & & $-6,63$ & 4,47 & 13,47 \\
\hline $\mathbf{C}$ & & & 50,45 & $-15,36$ & $-3,49$ \\
\hline $\mathbf{A}$ & & & 37,06 & 52,01 & 56,11 \\
\hline $\mathbf{M}$ & & & $-21,89$ & 23,78 & 48,90 \\
\hline$\overline{\mathbf{E}}$ & & & $-152,33$ & $-49,15$ & $-2,08$ \\
\hline $\mathbf{L}$ & & & $-6,95$ & 3,61 & $-27,98$ \\
\hline $\mathbf{S}$ & & & 20,26 & 2,71 & 0,82 \\
\hline Vakıf Katılım & & & & 23,05 & 25,00 \\
\hline $\mathrm{C}$ & & & & 59,43 & 10,55 \\
\hline $\mathbf{A}$ & & & & 32,30 & 50,46 \\
\hline $\bar{M}$ & & & & 29,87 & 44,11 \\
\hline $\mathbf{E}$ & & & & $-55,67$ & $-0,39$ \\
\hline $\mathbf{L}$ & & & & 38,04 & 15,21 \\
\hline $\mathbf{S}$ & & & & 19,15 & 26,37 \\
\hline
\end{tabular}

\subsection{Analiz Bulguları}

Türkiye de faaliyet gösteren katılım bankalarının 2013-2017 yılları arasındaki CAMELS analizi puanları tespit edilmiş olup, analiz sonuçlarına ilişkin ana bileşenlerinin puanları grafiklerde karşılaştırılması yapılarak yorumlanmıştır. 


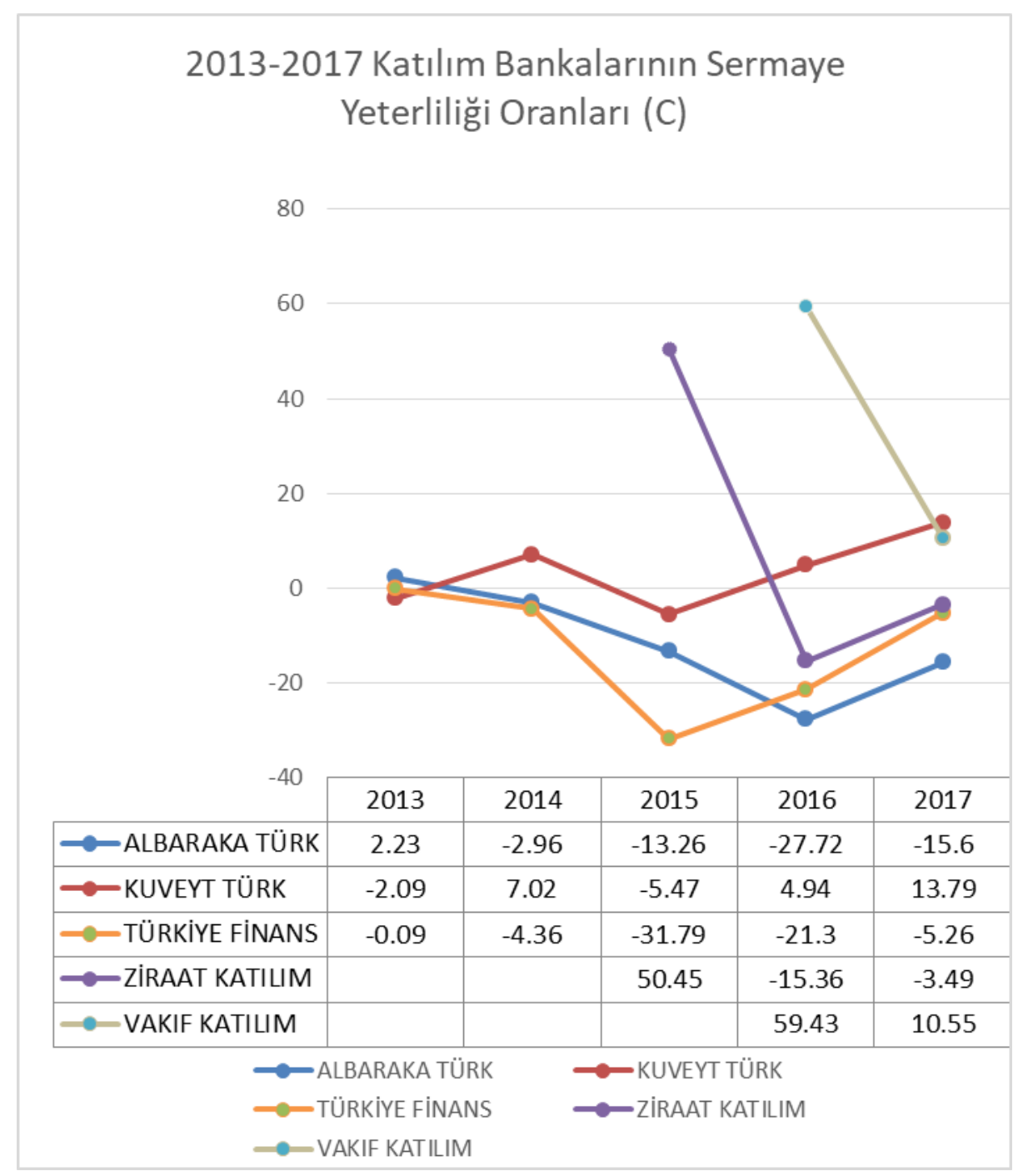

Grafik 1. 2013-2017 Katılım Bankalarının Sermaye Yeterliliği Oranları

Grafik 1'de elde edilen verilere göre 2013-2017 yılları arasındaki Sermaye Yeterlilik Oranında (C) en yüksek puan 2016 yılında 59,43 puanla Vakıf Katılım Bankasının olmuştur. Bu puanın yüksek olmasında (Öz Kaynaklar-Duran Aktifler)/Toplam Aktifler (SYO3) bileşen puanının yüksek olması etkili olmuştur. En düşük puan ise; 2015 yılında -31,79 puan ile Türkiye Finans Katılım Bankasının olmuştur. Bu puanın düşük olmasında SYO3 puanının düşük olması etkili olmuştur.

Albaraka Türk Katılım Bankası, 2013 yılındaki 2,23 puanından 2016 yılındaki -27,72 puanına kadar düşüş gösterip, 2017 yılındaki -15,6 puanına artış göstermiştir. Kuveyt Türk Katılım Bankası, 2013 yılındaki -2,09 puanından dalgalanmalar halinde 2017 yılındaki 13,79 puanına artış göstermektedir. Türkiye Finans Katılım Bankası, 2013 yılındaki -0,09 puanından 2017 yılındaki -5,26 puanına doğru düşüş göstermiştir. En büyük düşüşü 2015 yılındaki -31,79 puanı ile yaşamıştır. Ziraat Katılım Bankası 2015 yılında faaliyete başlamış olduğundan 2013 ve 2014 yılları değerlendirmeye alınmamıştır. Ziraat Katılım Bankası 2015 yılında 50,45 puanla başlangıç yaparak 2016 yılında sert bir düşüş yaşayıp, 2017 yılındaki -3,49 puanına doğru biraz yükselme göstermektedir. Vakıf Katılım Bankası 2016 yılında 
faaliyete başlamış olduğundan 2013, 2014 ve 2015 yılları değerlendirmeye alınmamıştır. Vakıf Katılım Bankası, 2016 yılında 59,43 puanla başlangıç yapıp 2017 yılındaki 10,55 puanına doğru sert bir düşüş yaşamıştır.

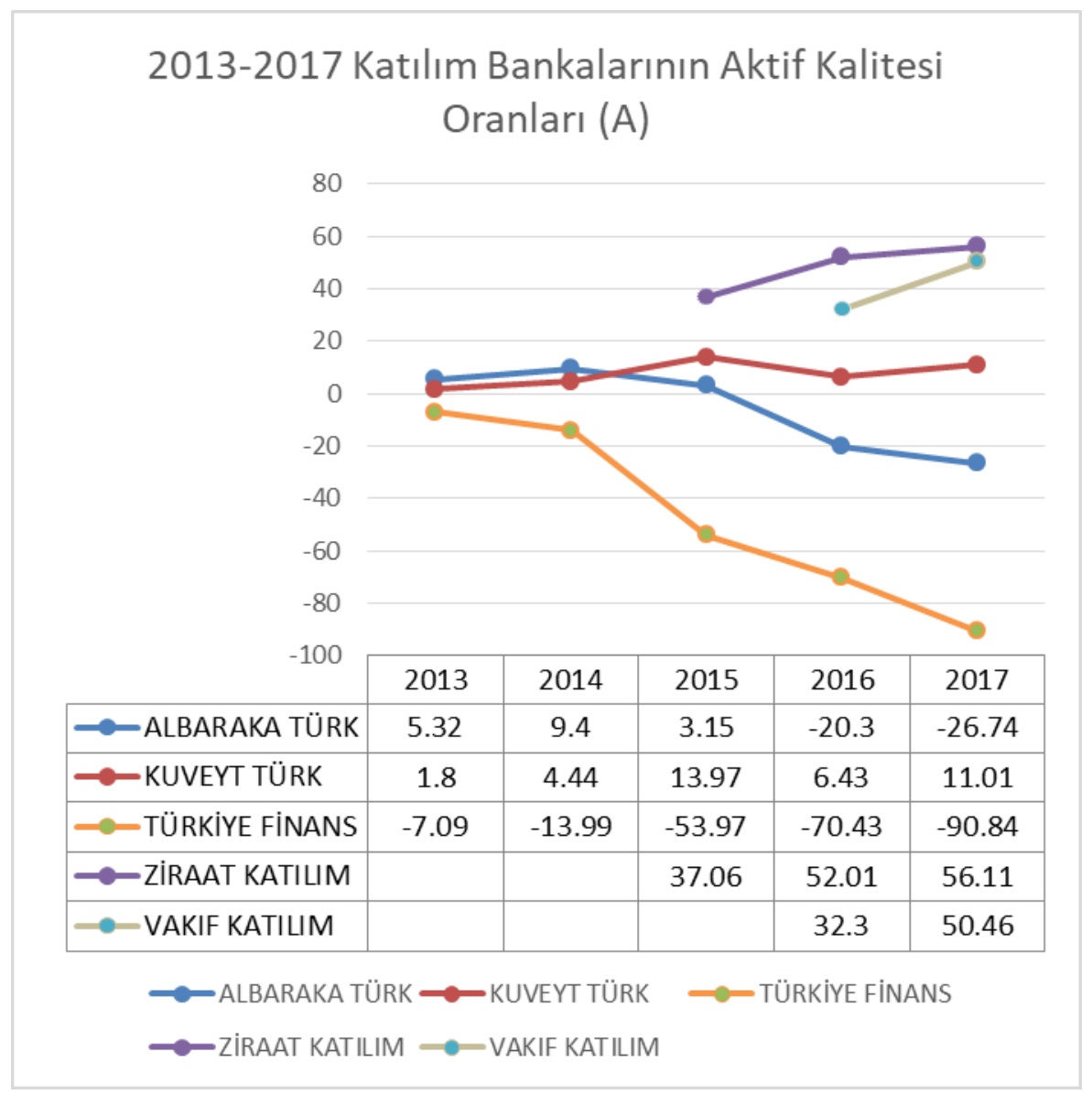

Grafik 2. 2013-2017 Katılım Bankalarının Aktif Kalitesi Oranları

Grafik 2'de elde edilen verilere göre 2013-2017 yılları arasındaki Aktif Kalitesi (A) oranında en yüksek puan 2017 yılında 56,11 puan ile Ziraat Katılım Bankasının olmuştur. Bu puanın yüksek olmasında Takipteki Krediler (brüt) / Toplam Krediler ve Alacaklar (AKO2) bileşen puanının yüksek olması etkili olmuştur. En düşük puan ise; 2017 yılında $-90,84$ puan ile Türkiye Finans Katılım Bankasının olmuştur. Bu puanın düşük olmasında Duran Aktifler / Toplam Aktifler (AKO3) puanının düşük olması etkili olmuştur.

Albaraka Türk Katılım Bankası, 2013 yılındaki 5,32 puanından 2017 yılındaki -26,74 puanına kadar düşüş göstermiştir. Kuveyt Türk Katılım Bankası, 2013 yılındaki 1,8 puanından 2015 yılında 13,97 puanına yükseldikten sonra 2017 yılındaki 11,01 puanına kadar doğru düşüş gerçekleştirmiştir. Türkiye Finans Katılım Bankası, 2013 yılındaki -7,09 puanından 2017 yılındaki -90,84 puanına doğru en hızlı düşüşü yaşamıştır. Ziraat Katılım Bankası 2015 yılında faaliyete başlamış olduğundan 2013 ve 2014 yılları değerlendirmeye alınmamıştır. Ziraat Katılım Bankası 2015 yılında 37,06 puanla başlangıç yaparak 2017 yılındaki 56,11 puanına düzenli olarak artış göstermiştir. Vakıf Katılım Bankası 2016 yılında faaliyete başlamış olduğundan 2013, 2014 ve 2015 yılları değerlendirmeye alınmamıştır 
Vakıf Katılım Bankası, 2016 yılında 32,3 puanla başlangıç yapıp, 2017 yılındaki 50,46 puanına doğru yükselme göstermiştir.

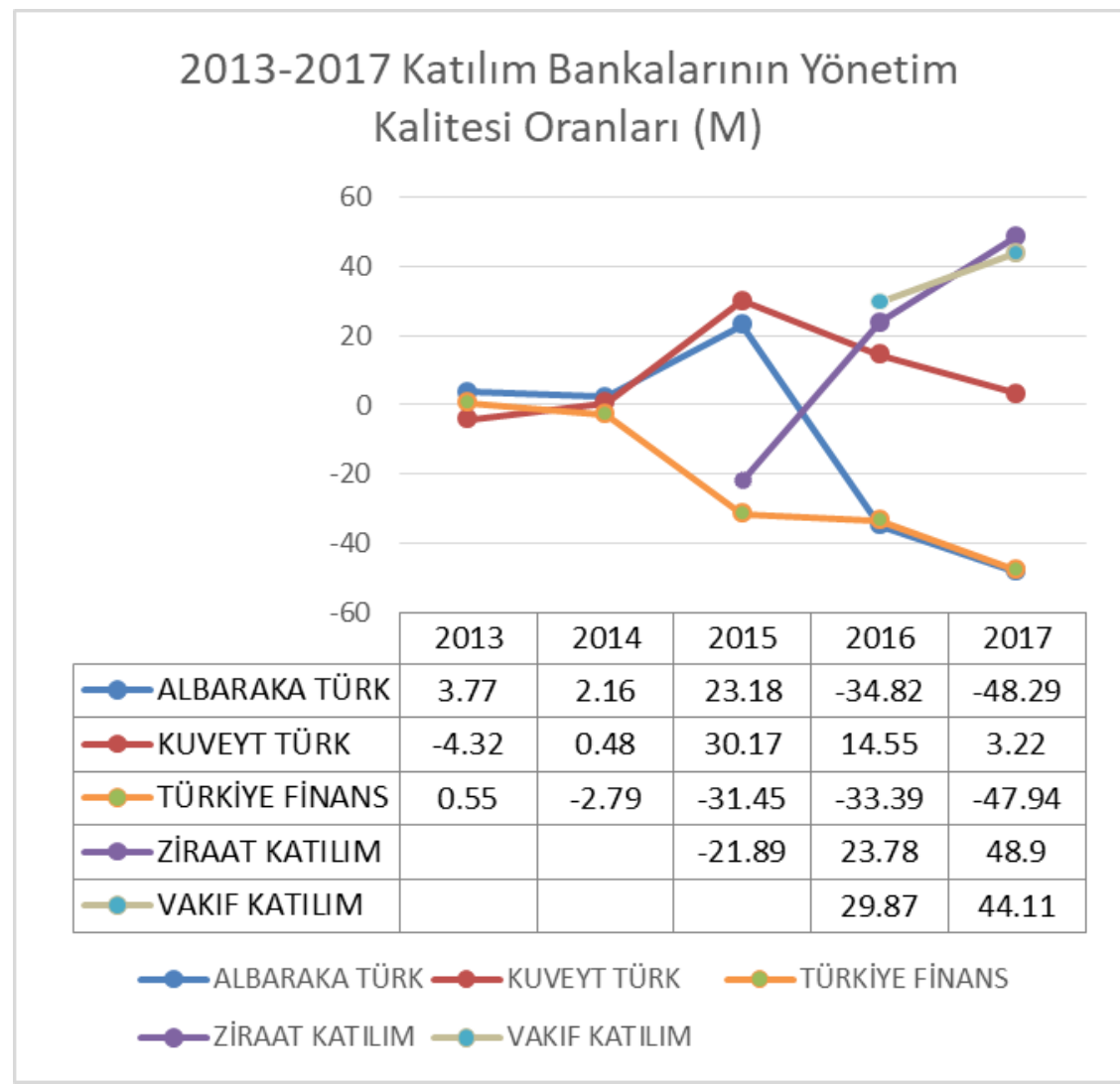

Grafik 3. 2013-2017 Katılım Bankalarının Yönetim Kalitesi Oranları

Grafik 3'te elde edilen verilere göre 2013-2017 yılları arasındaki Yönetim Kalitesi Oranında (M) en yüksek puan 2017 yılında 48,9 puan ile Ziraat Katılım Bankasının olmuştur. $\mathrm{Bu}$ puanın yüksek olmasında Takipteki Krediler (brüt) / Toplam Krediler ve Alacaklar (YKO1) bileşen puanının yüksek olması etkili olmuştur. En düşük puan ise; 2017 y1lında 48,29 puan ile Albaraka Türk Katılım Bankasının olmuştur. Bu puanın düşük olmasında YKO1 bileşen puanının düşük olması etkili olmuştur.

Albaraka Türk Katılım Bankası, 2013 yılındaki 3,77 puanından 2017 yılındaki -48,29 puanına dalgalanmalar halinde düşüş yaşamıştır. En hızlı düşüşü 2016 yılında yaşamıştır. Kuveyt Türk Katılım Bankası, 2013 yılındaki -4,32 puanından 2015 yılındaki 30,17 puanına kadar artış gösterdiyse de 2017 yılındaki 3,22 puanına doğru hızlı bir düşüş yaşamıştır. Türkiye Finans Katılım Bankası, 2013 yılındaki 0,55 puanından 2017 yılındaki -47,94 puanına doğru hızlı bir düşüş yaşamıştır. Ziraat Katılım Bankası 2015 yılında faaliyete başlamış olduğundan 2013 ve 2014 yılları değerlendirmeye alınmamıştır. Ziraat Katılım Bankası 2015 yılında -21,89 puanla başlangıç yaparak 2017 yılındaki 48,9 puanına doğru hızlı bir yükselme gerçekleştirmiştir. Vakıf Katılım Bankası 2016 yılında faaliyete başlamış olduğundan 2013, 2014 ve 2015 yılları değerlendirmeye alınmamıştır Vakıf Katıı̆ Bankası, 2016 yılında 29,87 puanla başlangıç yaparak 2017 yılındaki 44,11 puanına doğru yükselme göstermiştir. 


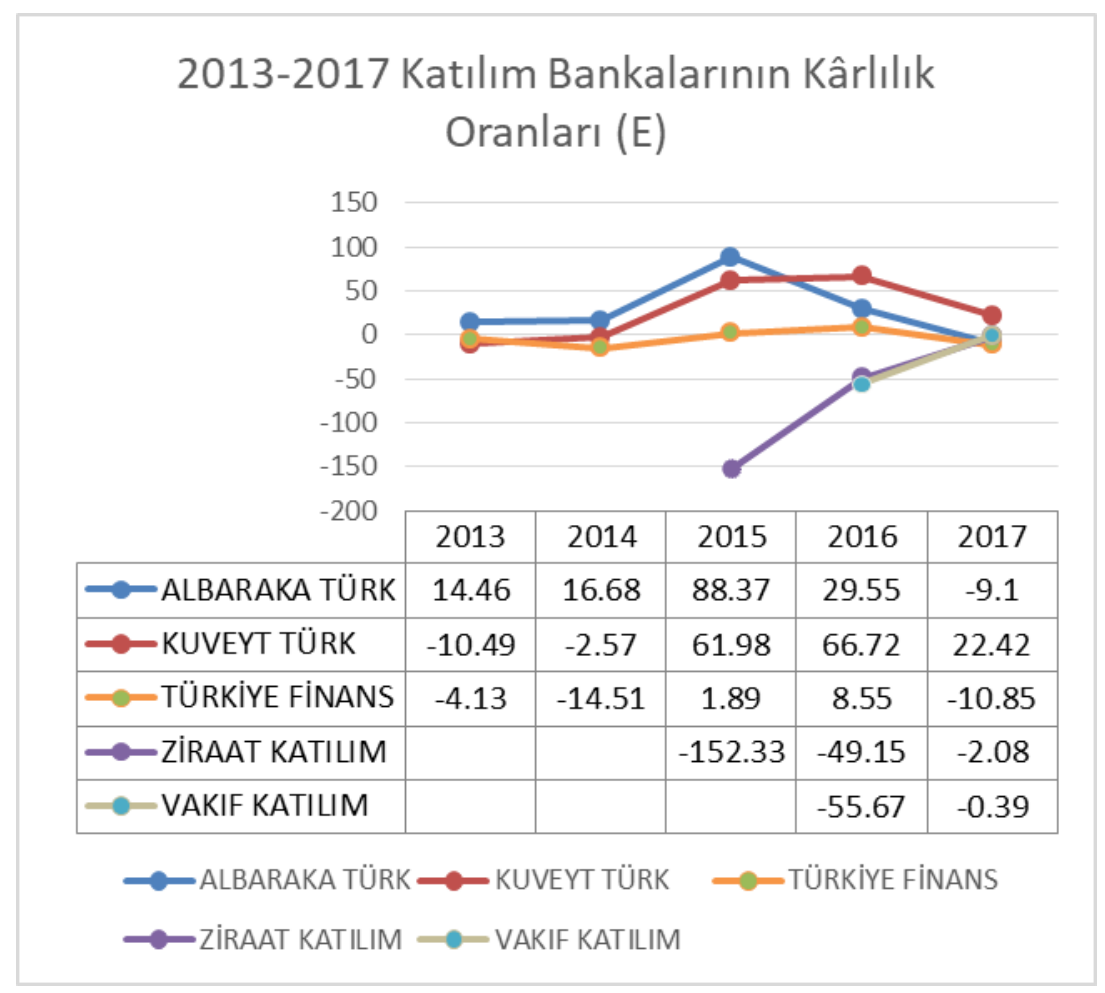

Grafik 4. 2013-2017 Katılım Bankalarının Kârlılık Oranları

Grafik 4'te elde edilen verilere göre 2013-2017 yılları arasındaki Kârlılık Oranında (E) en yüksek puan 2015 yılında 88,37 puanla Albaraka Türk Katılım Bankası olmuştur. Bu puanın yüksek olmasında Net Dönem Kârı (Zararı)/Ödenmiş Sermaye (KO4) bileşen puanının yüksek olması etkili olmuştur. En düşük puan ise; 2015 yılında -152,33 puanla Ziraat Katılım Bankasının olmuştur. Bu puanın düşük olmasında, Net Dönem Kârı (Zararı)/Toplam Aktifler (KO1) bileşen puanının düşük olması etkili olmuştur.

Albaraka Türk Katılım Bankası, 2013 yılındaki 14,46 puanından 2015 yılındaki 88,37 puanına kadar hızlı bir yükselme gerçekleştirmişse de 2017 yılındaki -9,1 puanına doğru sert bir düşüş yaşamıştır. Kuveyt Türk Katılım Bankası, 2013 yılındaki -10,49 puanından 2016 yılındaki 66,72 puanına hızlı bir yükselme gösterdikten sonra 2017 yılındaki 22,42 puanına doğru sert bir düşüş yaşamıştır. Türkiye Finans Katılım Bankası, 2013 yılındaki -4,13 puanından dalgalı bir şekilde 2017 yılındaki -10,85 puanına doğru bir düşüş yaşamıştır. Ziraat Katılım Bankası 2015 yılında faaliyete başlamış olduğundan 2013 ve 2014 yıılları değerlendirmeye alınmamıştır. Ziraat Katılım Bankası 2015 yılındaki -152,33 puanla başlangıç yaparak 2017 yılındaki -2,08 puanına doğru hızlı bir yükselme gerçekleştirmiştir. Vakıf Katılım Bankası 2016 yılında faaliyete başlamış olduğundan 2013, 2014 ve 2015 yılları değerlendirmeye alınmamıştır. Vakıf Katılım Bankası 2016 yılında -55,67 puanla başlangıç yaparak 2017 yılındaki -0,39 puanına doğru hızlı bir yükselme gerçekleştirmiştir. 


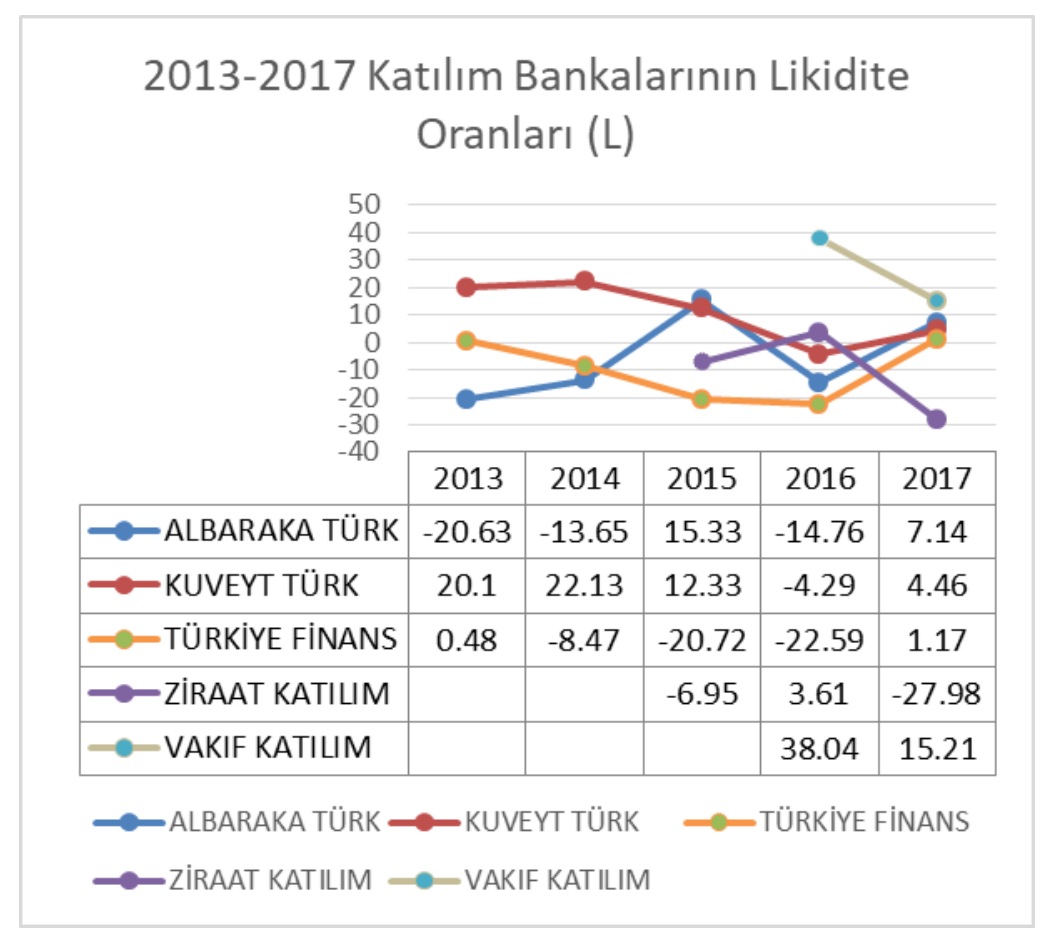

Grafik 5. 2013-2017 Katılım Bankalarının Likidite Oranları

Grafik 5'te elde edilen verilere göre 2013-2017 yılları arasındaki Likidite Oranında (L) en yüksek puan 2016 yılında 38,04 puanla Vakıf Katılım Bankasının olmuştur. Bu puanın yüksek olmasında Likit Aktifler/Kısa Vadeli Yükümlülükler (LO2) ve TP Likit Aktifler / Toplam Aktifler (LO3) bileşen puanlarının yüksek olması etkili olmuştur. En düşük puan ise; 2017 yılında -27,98 puanla Ziraat Katılım Bankasının olmuştur. Bu puanın düşük olmasında, Likit Aktifler / Toplam Aktifler (LO1) ve (LO2) bileşen puanlarının düşük olması etkili olmuştur.

Albaraka Türk Katılım Bankası, 2013 yılındaki -20,63 puanından dalgalı bir şekilde 2017 yılındaki 7,14 puanına doğru yükselme gerçekleştirmiştir. Kuveyt Türk Katılım Bankası, 2013 yılındaki 20,1 puanından dalgalı bir şekilde 2017 yılındaki 4,46 puanına doğru düşüş yaşamıştır. Türkiye Finans Katılım Bankası, 2013 yılındaki 0,48 puanından 2016 yılındaki $\quad-22,59$ puanına doğru düşüş yaşayıp, 2017 yılındaki 1,17 puanıyla yükselme gerçekleştirmiştir. Ziraat Katılım Bankası 2015 yılında faaliyete başlamış olduğundan 2013 ve 2014 yılları değerlendirmeye alınmamıştır. Ziraat Katılım Bankası 2015 yılındaki -6,95 puanından başlangıç yaparak, 2016 yılındaki 3,61 puanına yükseldikten sonra 2017 yılındaki 27,98 puanına doğru sert bir düşüş yaşamıştır. Vakıf Katılım Bankası 2016 yılında faaliyete başlamış olduğundan 2013, 2014 ve 2015 yılları değerlendirmeye alınmamıştır. Vakıf Katılım Bankası 2016 yılında 38,04 puanla başlangıç yaparak, 2017 yılındaki 15,21 puanına doğru düşüş yaşamıştır. 


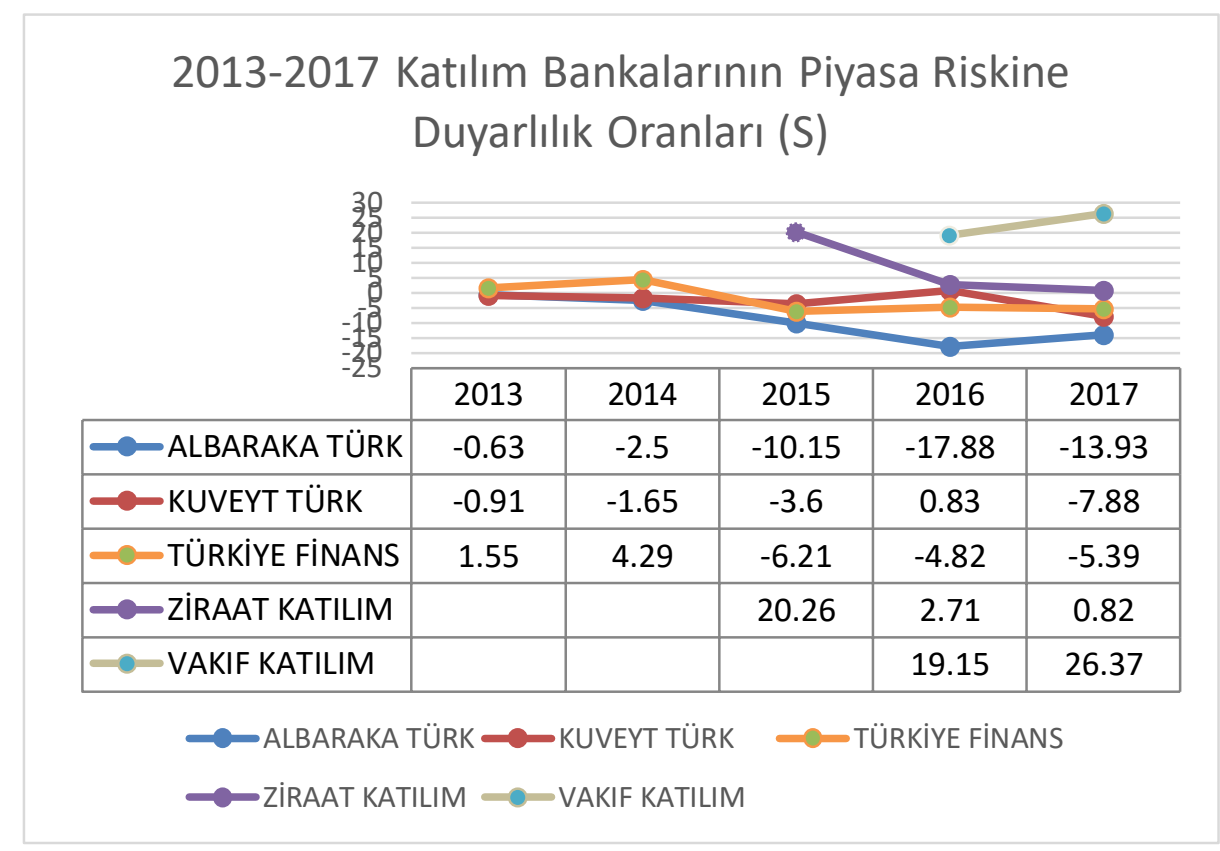

Grafik 6. 2013-2017 Katılım Bankalarının Piyasa Riskine Duyarlılık Oranları

Grafik 6'da elde edilen verilere göre 2013-2017 yılları arasındaki Piyasa Riskine Duyarlılık Oranında (S) en yüksek puan 2017 yılında 26,37 puanla Vakıf Katılım Bankasının olmuştur. Bu puanın yüksek olmasında Döviz Pozisyonu / Öz kaynaklar (PRDO3) bileşen puanının yüksek olması etkili olmuştur. En düşük puan ise; 2016 yılında $-17,88$ puanla Albaraka Türk Katılım Bankasının olmuştur. Bu puanın düşük olmasında, PRDO3 bileşen puanının düşük olması etkili olmuştur.

Albaraka Türk Katılım Bankası, 2013 yılındaki -0,63 puanından 2016 yılındaki -17,88 puanına kadar düşüş yaşayıp, 2017 yılındaki -13,91 puanına doğru yükseliş gerçekleş̧irmiştir. Kuveyt Türk Katılım Bankası, 2013 yılındaki $-0,91$ puanından 2015 yılındaki -3,6 puanına kadar düşüş yaşayıp, 2016 yllındaki 0,83 puanına doğru yükseliş gerçekleştirmişse de 2017 yılında tekrar -7,88 puanına doğru düşüs yaşamıştır. Türkiye Finans Katılım Bankası, 2013 yılındaki 1,55 puanından 2017 yılındaki -5,39 puanına doğru dalgalı olarak düşüş yaşamıştır. Ziraat Katılım Bankası 2015 yılında faaliyete başlamış olduğundan 2013 ve 2014 yılları değerlendirmeye alınmamıştır. Ziraat Katılım Bankası 2015 yılındaki 20,26 puanından 2017 yılındaki 0,82 puanına doğru sert bir düşüş yaşamıştır. Vakıf Katılım Bankası 2016 yılında faaliyete başlamış olduğundan 2013, 2014 ve 2015 yılları değerlendirmeye alınmamıştır Vakıf Katılım Bankası 2016 yılında 19,15 puanla başlangıç yaparak, 2017 yılındaki 26,37 puanına doğru yükselme gerçekleştirmiştir. 


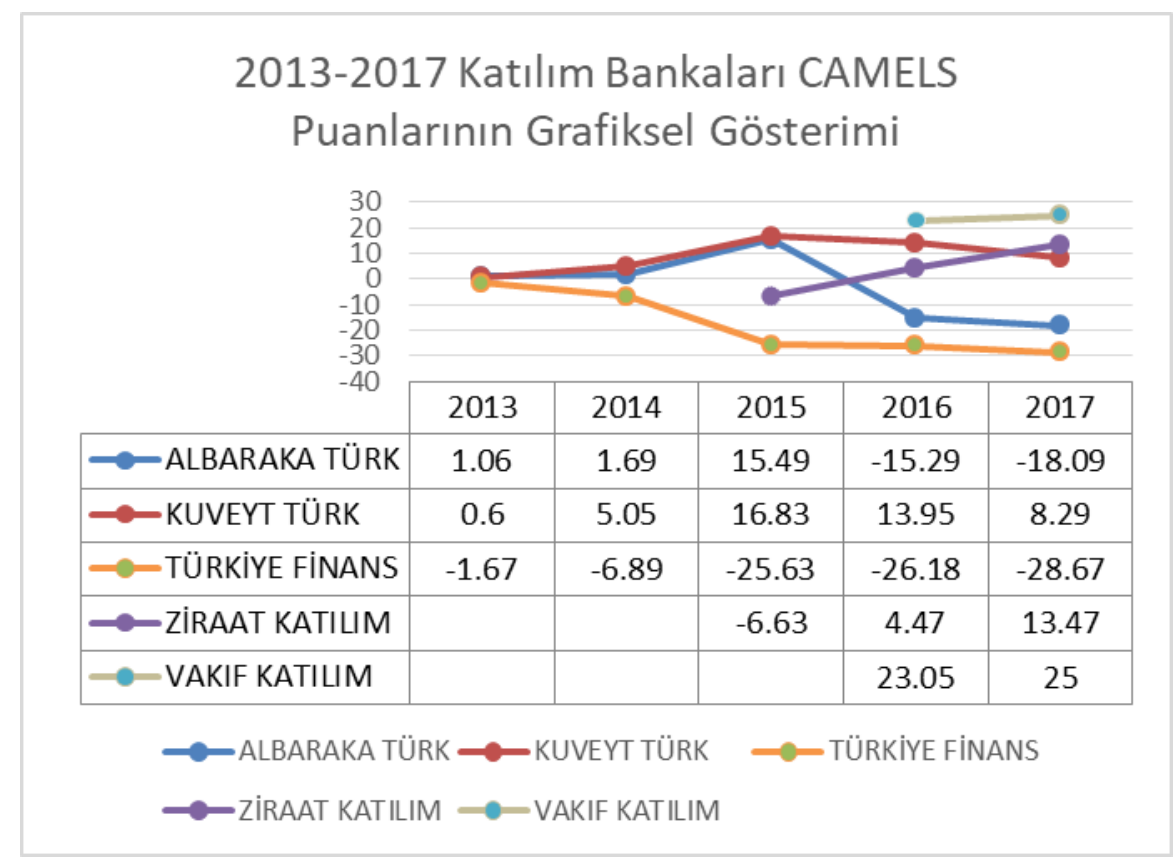

Grafik 7. 2013-2017 Katılım Bankaları CAMELS Puanlarının Grafiksel Gösterimi

Grafik 7'de elde edilen verilere göre 2013-2017 yılları arasındaki CAMELS puanlarından en yüksek olanı 2017 yılında 25 puanla Vakıf Katılım Bankasının olmuştur. Bu puanın yüksek olmasında Aktif Kalitesi Oranı (A) ana bileşen puanının yüksek olması etkili olmuştur. En düşük puan ise; 2017 yılında -28,67 puanla Türkiye Finans Katılım Bankasının olmuştur. Bu puanın düşük olmasında, "A" ana bileşen puanının düşük olması etkili olmuştur.

Albaraka Türk Katılım Bankası, 2013 yılındaki 1,06 puanından 2015 yılındaki 15,49 puanına doğru yükselme gerçekleştirip, 2017 yılındaki -18,09 puanına doğru düşüş yaşamıştır. Kuveyt Türk Katılım Bankası, 2013 yılındaki 0,6 puanından 2015 yılındaki 16,83 puanına doğru yükselme gerçekleştirip, 2017 yılındaki 8,29 puanına doğru düşüş yaşamıştır. Türkiye Finans Katılım Bankası, 2013 yılındaki -1,67 puanından 2017 yılındaki -28,67 puanına doğru düzenli bir şekilde düşüş yaşamıştır. Ziraat Katılım Bankası 2015 yılında faaliyete başlamış olduğundan 2013 ve 2014 yılları değerlendirmeye alınmamıştır. Ziraat Katılım Bankası 2015 yılındaki -6,63 puanından başlangıç yaparak 2017 yılındaki 13,47 puanına doğru yükselme gerçekleştirmiştir. Vakıf Katılım Bankası 2016 yılında faaliyete başlamış olduğundan 2013, 2014 ve 2015 yılları değerlendirmeye alınmamıştır. Vakıf Katılım Bankası 2016 yılında 23,05 puanından başlangıç yaparak, 2017 yılındaki 25 puanına doğru yükselme gerçekleştirmiştir.

\section{SONUÇ VE ÖNERILER}

CAMELS analizi, ortaya çıkabilecek risklere ve problemlere karşı önceden önlem alınması konusunda önemli bir yere sahiptir. CAMELS analizi bankaların güçlü ve zayıf yönlerini belirleyerek, genel durumu hakkında bilgi vermektedir. CAMELS analizi sonuçları erken uyarı sistemi olarak da ifade edilmektedir. 
Çalışmanın uygulama bölümünde ise Türkiye'de faaliyet göstermekte olan 5 katılım bankasının 2013-2017 yılları arasındaki CAMELS analizi yapılmış olup, veriler arası karşılaş̧ırmalar yapılarak 5 katılım bankasının performans ölçümü yapılmıştır. Yapılan analizler doğrultusunda elde edilen sonuçlar şöyledir:

- Albaraka Türk Katılım Bankası 2014 yılından itibaren Sermaye Yeterlilik Oranı (C), Aktif Kalitesi Oranı (A), 2015 yılından itibaren Yönetim Kalitesi Oranı (M), Kârlılık Oranı (E), Likidite Oranı (L), 2013 yılından itibaren Piyasa Riskine Duyarlılık Oranı (S) , 2015 yılından itibaren CAMELS puanlarında belirgin bir şekilde düşüş yaşamıştır.

- Kuveyt Türk Katılım Bankası 2015 yılından itibaren Yönetim Kalitesi Oranı (M), 2014 yılından itibaren Likidite Oranı (L), 2017 yılında Kârlılık Oranı (E) ve Piyasa Riskine Duyarlılık Oranı (S), 2015 yılından itibaren CAMELS puanlarında düşüş yaşamıştır.

- Türkiye Finans Katılım Bankası 2015 yılında Sermaye Yeterlilik Oranı (C), 2013 yılından itibaren Aktif Kalitesi Oranı (A), Yönetim Kalitesi Oranı (M), Likidite Oranı (L), 2014 ve 2017 yıllarında Kârlılık Oranı (E), 2013 yılından itibaren CAMELS puanlarında belirgin bir şekilde düşüş yaşamıştır.

- Ziraat Katılım Bankası 2015 y1lında faaliyete başlamış olup, devlete ait olmasından dolayı yüksek sermaye yapısına rağmen olaylara karşı daha hassasiyet gösterebilmektedir. Bu durum da 2015 yılından itibaren Sermaye Yeterlilik Oranı (C), 2017 yılında Likidite Oranı (L), 2015 yılında itibaren Piyasa Riskine Duyarlılık Oranı (S) puanlarında belirgin bir şekilde düşüş yaşamıştır.

- Vakıf Katılım Bankası 2016 yılında faaliyete başlamış olup, 2017 yılında Sermaye Yeterlilik Oranı (C), Likidite Oranı (L) puanlarında belirgin bir şekilde düşüş yaşamışıtr.

Çalışmanın sonuçlarından hareketle, küresel anlamda yaşanan gelişsmelerin (Büyüme hızı, Küresel ve jeopolitik etki, Ortadoğu'da yaşanan gelişmeler, AB üyelik süreci) finansal sektör olan katılım bankacılığı sistemine etkileri kaçınılmazdır.

Katılım bankacılığı sistemindeki bankaların CAMELS analizi puanlarında olumsuzluk yaşanmaması için bu analizin bileşenleri etkin bir şekilde değerlendirilmelidir. Katılım bankalarının sermaye yapısı korunmalıdır. Aktif Kalitesi içinde olan kredi kalemine önem verilmelidir. Yönetim yeterliliği bankalar için yüksek önem teşkil etmektedir. Yönetimin olaylara anında müdahale edebilme ve krizleri yönetebilme becerileri olması gerekmektedir. Kazanç durumunda, bankaların faaliyetlerini uzun süre devam ettirebilmeleri için sürekli ve artan seyirde kâr elde etmeleri gerekmektedir. Likidite Durumu, bankaların mevduat, borç ve kredi yükümlülüklerini eksiksiz olarak yerine getirmeleri ile ilişkilidir. Piyasa risklerine duyarllık; değişen kredi riski, piyasa riski, operasyonel risk, döviz riski ve likidite riski gibi birçok faktörü ifade etmektedir.

Çalışmada öneri olarak; CAMELS analizinin başka sektörlerde faaliyet gösteren bugün için kârlı olarak devam eden ancak ileride riskli durumlarda karşı karşıya kalabilecek sektörlerdeki işletmeler için de yıllar itibariyle uygulamasının zorunluluk haline getirilmesinin hem ülke ekonomisi için önemli olacağı hem de ülke istihdamını artırıp ithalata dayalı bir konumdan ihracata dayalı hale gelinmesine yardımcı olacağı düşünülmektedir. 


\section{KAYNAKLAR}

Abdullayev, Mezahir. (2013). "Türk Bankaclık Sektöründe Dezenflasyon Sürecinde Camels Analizi”, Dumlupınar Üniversitesi Sosyal Bilimler Dergisi, 37, ss. 97-112

Altan, Mikail. (2001). Fonksiyonlar ve İşlemler Açısından Bankacılık. İstanbul: Beta Basım.

Ateşoğlu Coşkun, Sevda - Karğın, Sibel. (2016). "Sınır Ötesi Birleşme ve Satın Almaların Bankaların Finansal Performansına Etkileri: Üç Banka Üzerinde CAMELS Analizi”, Muhasebe ve Finansman Dergisi, 69, ss. 41-59.

Arıçelik, Gülçin. (2010). Ticari Bankalarda Performans Ölçümü: CAMELS Analizine Dayalı Bir İnceleme. T.C. Dokuz Eylül Üniversitesi, Sosyal Bilimler Enstitüsü, İktisat Anabilim Dalı,Para ve Banka Programı, Yüksek Lisans Tezi, İzmir.

Avcu, Emir, C. (2015). Katılım Bankacılı̆̆ı ve Sukuk Modelleri, T.C. Süleyman Demirel Üniversitesi Sosyal Bilimler Enstitüsü İşletme Anabilim Dalı, Yüksek Lisans Tezi, Isparta.

Aytekin, Sinan - Sakarya, Şakir. (2013). "BIST'deki Mevduat Bankalarının Finansal Performanslarının 2001 ve 2008 Finansal Krizleri Çerçevesinde CAMELS Derecelendirme Sistemi ile Değerlendirilmesi”, Abant İzzet Baysal Üniversitesi Sosyal Bilimler Enstitüsü Dergisi, ss. 25-58.

Çağıl, Gülcan - Mukhtarov, Shahriyar. (2014). "Azerbaycan Ticari Bankacıllk Sektörünün Camels Yöntemi İle Performans Analizi”, Marmara Üniversitesi Öneri Dergisi, 11(41), ss. 77-94.

Çelik, Pelin. (2004), Bankaların Risk Derecelendirmesi, Türkiye Cumhuriyeti Merkez Bankası, Uzmanlık Yeterlilik Tezi, Ankara.

Dash, Mihir - Das, Annyesha. (2010), "A CAMELS Analysis of the Indian Banking Industry", papers.ssrn.com/sol3/papers.cfm?abstract_id=1666900.

Ege, İlhan - Topaloğlu, Emre - Karakozak, Özlem (2015). “CAMELS Performans Değerleme Modeli: Türkiye'deki Mevduat Bankaları Üzerine Ampirik Bir Uygulama”, Ömer Halisdemir Üniversitesi İktisadi ve İdari Bilimler Fakültesi Dergisi, 8(4), ss. 109-126.

El Qorchi, Mohammed (2005). "Islamic Finance Gears Up", 42(4), Finance and Development.

Eskici, Mustafa, M. (2007). Türkiye'de Katılım Bankacıllğı Uygulaması ve Katılım Bankaları’nın Müşteri Özellikleri. Süleyman Demirel Üniversitesi, Yüksek Lisans Tezi, Isparta.

Gümüş, Fatih, B. - Nalbantoğlu, Önder (2015). "Türk Bankacıllk Sektörünün CAMELS Analizi Yöntemiyle 2002-2013 Yılları Arasında Performans Analizi”, Afyon Kocatepe Üniversitesi İktisadi ve İdari Bilimler Fakültesi Dergisi, 17(2), ss. 83-106. 
Iqbal, Munawar - Molyneux, Philip (2005). "Thirty Years of Islamic Banking. New York: Palgrave Macmillan", History, Performance and Prospects. Springer.

Kandemir, Tuğrul - Demirel Arıcı, Nuray (2013). "Mevduat Bankalarında CAMELS Performans Değerleme Modeli Üzerine Karşılaştırmalı Bir Çalışma (2001-2010)", Süleyman Demirel Üniversitesi İktisadi ve İdari Bilimler Fakültesi Dergisi, 18(1), ss. 61-87.

Karhan, C. (2015). Katılım Bankacılığı ve Türkiye'deki Katılım Bankalarının Etkinlik ve Verimliliklerinin Ölçülmesi, T.C. Atatürk Üniversitesi Sosyal Bilimleri Enstitüsü İşletme Anabilim Dalı, Yüksek Lisans Tezi.

Özulucan, Abitter - Deran, Ali (2009). "Katılım Bankacilığı ile Geleneksel Bankaların Bankacılık Hizmetleri ve Muhasebe Uygulamaları Açısından Karşılaştııılması", Mustafa Kemal Üniversitesi Sosyal Bilimler Enstitüsü Dergisi , 6(11), ss. 85-108.

Parasız, İlker, M. (2000). Modern Bankacılık Teori ve Uygulama. İstanbul: Kuşak Yayınları.

Sunbat, A. (2016). Katılım Bankacılığı. T.C. Hasan Kalyoncu Üniversitesi, Sosyal Bilimler Enstitüsü, İktisat Anabilim Dalı, Tezli Yükseklisans Programı, Yüksek Lisans Tezi, Gaziantep.

Türkmenoğlu, Rüveyde, E. (2007). Katılım Bankacıllı̆ı 1 ve Türkiye'deki Finansal Yapı. Yüksek Lisans Tezi, Kırıkkale, Kırıkkale Üniversitesi.

Türker Kaya, Yasemin (2001). Türk Bankacılık Sektöründe CAMELS Analizi. Ankara: BDDK Mali Sektör Politikaları Dairesi Çalışma Raporları, Eylül, No: 2001/6.

Williams, Harley. Tega. (2011). "Determinants of capital adequacy in the Banking Sub-Sector of the Nigeria Economy: Efficacy of Camels.(A Model Specification with CoIntegration Analysis)." International Journal of Academic Research in Business and Social Sciences, 1(3), pp. 233.

www.tbb.org.tr/Content/Upload/Dokuman/7453/Turkiye'de_Bankacilik_Sektoru_20132017_Eylul.pdf/ (16 Mart 2018).

www.turkiyefinans.com.tr/tr-tr/hakkimizda/katilim-bankaciligi-sistemi/Sayfalar/katilimbankaciligi-nasil-isler.aspx/ (16 Ocak 2018). 
